\title{
Teaching Research of Mobile Communication Technology and Modern Civilization based on Lecture
}

\author{
Gao Guangchun 1, a, Xiong Kai, , , Fang Jian ${ }^{1, ~ c}$, Zhou Xuanchang, d \\ ${ }^{1}$ School of Information \& Electrical Engineering, Zhejiang University City College, Hang Zhou, \\ 310015, China \\ aGaogc@zucc.edu.cn, bXiongk@zucc.edu.cn, cfangjian@zucc.edu.cnl, dzhouxc@zucc.edu.cnl
}

Keywords: Communications technology, teaching method, lecture

\begin{abstract}
General education is an important part of higher education in China. General education affects the free comprehensive development of college students. This paper expounds the necessity of the purpose of general education and its implementation. This paper puts forward a teaching method based on the lecture forms. This paper expounds the teaching system and teaching content in detail of mobile technology and modern civilization.
\end{abstract}

\section{Introduction}

General education comes from the ancient Greek concept of free education in order to promote students comprehensive and harmonious development. General education is the important part in the university overall education in order to develop the initiative, socially responsible and comprehensive development students.

In the early 1980s, general education aroused the concern of the higher education. In the 1990s general education becomes a hot problem in the study on domestic institutions of higher learning reform of course system. General education has achieved good effect now. However, independent colleges for the exploration and practice of general education are still relatively weak. Independent colleges generally depend on the matrix public colleges and universities. But the talents cultivation orientation determines the independent colleges can not copy public university education mode.As is known to all, the student's culture quality of the independent college is lower than ordinary undergraduate students in general. They don't develop good study habits and consciousness. So, this paper put forward the improvement method. It put forward the form of lectures combined with a variety of teaching methods of general teaching methods.

\section{The necessity of the general education of communication}

General course is a combination of interdisciplinary knowledge. It's not the same as professional education. General education hopes to improve the ability of making better life. University is not only learning professional technology, humanities and life quality is also very important. In fact we want the student of science have humanities, and the humanities have scientific literacy.

Today society has entered the information society. The means of communication is increasing day by day. The microelectronics technology is developed rapidly. Wireless network coverage in great quantities. The multimedia technology develops rapidly. It changed the human's life and quality of life. So, as a participant in modern society, it is necessary to understand the basic knowledge of information science. As a social and economic builder, it is more necessary to understand the basic development of information science. So the construction of the general education of the mobile communication technology and modern civilization is very important. Most of the general curriculum is the computer class. The liberal arts students could not understand the development of modern science, unable to contact the forefront of information science, and can not use a scientific mind to face the challenges of information society. So it is necessary to open the information general curriculum to all the students. 


\section{Teaching content}

This course is for students who are not information technology students. Students don't need to take any courses. This course mainly teaches wireless communication technology, IC, multimedia communication and new technology. The course introduces the concept and at the same time uses case teaching, to let the students to understanding, interesting and mastering the basic theory of information science. Course teaching has two phases. The first stage focuses on communication, IC, multimedia communication and the basic knowledge of new technologies. It expands the knowledge field of students, strengthen the competitiveness.

The second phase focuses on case teaching and lectures to macro view extension students in science and technology application. We hope that students have learned is not only the scientific knowledge, but also the ability to available to the industry and to improve the human living standards. Then students should have the following ability eventually:

$\diamond$ Understand the mobile communication technology and the concept of modern civilization.

$\diamond$ Understand the basic concept and technical communication.

$\diamond$ Understand the future development direction of the communication industry.

In order to arouse the enthusiasm of students, we will arrange professional teachers in terms of his expertise according to different teaching links. We want our students to have a basic understanding of the electronic knowledge of everyday life, also will be interested in it. We also hope that teachers will put these topics is life, can be very close to people's lives. We hope students find that technology is not so cold and hope that they will be able to enjoy. The students need to know the basic concept of communications technology and at the future they can take advantage of mobile communication technology for their professional services. Students can make learning to listen to story. The course includes the following lecture:

$\diamond$ Communications technology and industrial development in China;

$\diamond$ The world is flat--spread spectrum communication;

$\diamond$ Technology began in human nature--mobile and wireless communications;

$\diamond$ From analog to digital--The first and second generation of mobile communication;

$\diamond$ Data time--the third generation mobile communication;

$\diamond$ Colorful multimedia technology;

$\diamond$ Ray photoelectric science and technology;

$\diamond$ From quantum mechanics to the sublime beauty of semiconductor components -- a winding road;

$\diamond$ Nanotechnology--atomic scale;

$\diamond$ Gold silicon-- integrated circuit design;

$\diamond$ Clouds deep place--cloud computing;

$\diamond$ Wisdom earth--the Internet of things;

$\diamond$ The charm of optimization--compressed sensing;

\section{Teaching method}

At present many university think that general elective course is the only additional lesson outside undergraduate major courses. It's Ignored in the teaching system. Students are not serious, or just in order to increase the interest.If the general elective course teaching content can't stimulate students' learning enthusiasm, teaching method can't guide students to active learning, students may be degraded into mixed credit courses. To solve above problems, we adopted the following teaching method to improve the students' learning interest and control the quality of teaching.

We use the multimedia teaching methods, provide students with the picture of the large amount of information data and application cases. The PPT uses text as less as possible and provides more pictures to increase students' interest in learning. 
We provide video case teaching, every time after the video learning, organize students to discuss, and then the teacher carries on the analysis and review.

We use BB platform organize students to participate in the course of discussion. Each student must attend at least two problem's discussion. We give bonus reward to students who answer the question best to encourage students to participate in the discussion.Because the present college students like to accept new things, so teachers use communication tools such as QQ, E-mail, weibo and WeChat to answer questions from the students and regular students participate in discussions.

The score is mainly based on students' discuss and course report.

\section{Teaching experience}

Our teaching experience is as follows:

$\diamond$ Communication teaching content broaden the students' knowledge. The students of Mobile communication technology and the modern civilization are close to 100. Students understand the basic concepts of communication and common sense. It increases the students' electronics knowledge.

$\diamond$ Students enhanced interest through lectures. This course conducted by five teachers, and teaching process simple, stimulated the students' thirst for knowledge. In the course report, many students put forward the development direction of the communication technology combined with their major. Such as a new idea of $3 \mathrm{~d}$ information acquisition based on communication technology, and Video images care.So through the study, students not only broaden the knowledge, but also promote the new way of thinking about the professional development.

$\diamond \quad$ The teaching methods and means still need to improve. Because the number of students is very large, the effect is not ideal. We want to divide classes into small classes to discuss to form large lectures and small workshops.

\section{Students response}

Each of the students have different learning experience, some typical briefly under different situations is as followings:

$\diamond$ Broaden the knowledge, learned some basic knowledge of science and technology of Telecommunication;

$\diamond$ Enhancing the students' interests in the form of lecture;

$\diamond$ More strengthening the group discussion to motivate the students;

$\diamond$ More video information is used in teaching.

\section{Concusion}

General education is an important part of contemporary higher education, This paper explores the Independent Institute of the teaching methods and ideas by analyzing the construction of Telecommunication technology and the general course of modern civilization, teaching content and teaching ideas, it hopes to explore a practical way to develop a more comprehensive individual.

\section{Acknowledgement}

This research was financially supported by the special professional construction project of communication engineering in Hang Zhou. 


\section{Reference:}

[1]. Zheng jie, talk about the necessity of general education and path analysis, science and education wenhui, 2010.02, pp. 1-2

[2]. Chow hown, problems and countermeasures of independent college general education, adult education in China, 2010.02, pp. 55-56

[3]. Yin Manfen, effective teaching case analysis of university general education course, Dali college journal, vol. 12201, 3.03, 80-84

[4]. Yang, zhe, university of science and engineering implementation of general education, the present situation and development countermeasure of journal of northwestern polytechnical university (social science edition), 2010.03, vol. 30,84-87.

[5]. Zhang Yifan, general education and university characteristics, development and evaluation of higher education, vol. 26, no. 1 2010,65-69. 